\title{
MEASUREMENT TECHNIOUES FOR SINGLE JUNCTION THERMOPHOTOVOLTAIC CELLS
}

$$
\text { CONF-981055-- }
$$

L. R. Danielson, J. R. Parrington, G. W. Charache, G. J. Nichols, D. M. DePoy

October 1998

DISTRIBUTION OF THS DOCUAENT IS UAKMITED

\section{NOTICE}

This report was prepared as an account of work sponsored by the United States Government. Neither the United States, nor the United States Department of Energy, nor any of their employees, nor any of their contractors, subcontractors, or their employees, makes any warranty, express or implied, or assumes any legal liability or responsibility for the accuracy, completeness or usefulness of any information, apparatus, product or process disclosed, or represents that its use would not infringe privately owned rights.

Operated for the U. S. Department of Energy

by KAPL, Inc. a Lockheed Martin company 


\section{DISCLAIMER}

This report was prepared as an account of work sponsored by an agency of the United States Government. Neither the United States Government nor any agency thereof, nor any of their employees, makes any warranty, express or implied, or assumes any legal liability or responsibility for the accuracy, completeness, or usefulness of any information, apparatus, product, or process discloced, or represents that its use would not infringe privately owned rights. Reference herein to any speciric commercial product, process, or service by trade name, trademark, inanufacturer, or otherwise does not necessarily constiute or imply its endorsement, recommendation, or favoring by the United States Governmeat or any agency thereof. The views and opinions of authors expressed herein do not necessarily state or reflect those of the United States Government or any agency thereof. 


\section{DISCLAIMER}

Portions of this document may be illegible in electronic image products. Images are produced from the best available original document. 


\title{
Measurement Techniques for Single Junction Thermophotovoltaic Cells
}

\author{
L.R. Danielson, J.R. Parrington, G.W. Charache, G. J. Nichols, and \\ D.M. Depoy
}

Bin 103, Lockheed Martin, Inc., 2401 River Road, Niskayuna, NY 12309

\begin{abstract}
Several measurement systems and techniques for the electrical and thermal characterization of thermophotovoltaic(TPV) cells are discussed. One computer controlled system measures the quantum efficiency of cells from 0.8 to 2.6 microns. A probe resistor is used to account for cells with low shunt resistances. In the second system, a production-style robot provides automated measurements of I-V characteristics under dark, blackbody, and flashed illumination conditions. The system measures the length and width of each cell, and calculates the open circuit voltage, short circuit current, fill factor, and maximum power for each cell. The mean and standard deviation of the measured parameters are also computed. The third system measures the overall cell efficiency by a calorimetric technique. Heat losses due to radiation, conduction, and convection are factored into the analysis method.
\end{abstract}

\section{INTRODUCTION}

Accurate measurements of electrical and thermal properties of thermophotovoltaic(TPV) cells are important to improve such cells, and to provide a basis for arranging the cells in a generator configuration. Experimental test systems to measure quantum efficiency vs. wavelength as well as dark and light I-V response curves have been developed. Also, the overall efficiency test for a single cell (1) has been modified and is described.

\section{QUANTUM EFFICIENCY MEASUREMENTS}

The external quantum efficiency (QE) of a TPV cell is defined as the probability that an incident photon will create an electron-hole pair that contributes to the current 
produced by the cell. The internal quantum efficiency of the cell is the external quantum efficiency divided by one minus the wavelength dependent reflection. The generated current and overall efficiency of a cell are proportional to the photonweighted average internal quantum efficiency (2).

An experimental system for measuring the external quantum efficiency has been developed. A monochrometer illuminator $(63 \mathrm{~W})$ provides the incident radiation, which passes through a $167 \mathrm{~Hz}$ chopper before entering the two-grating monochrometer. Three filters are cycled in as the wavelength varies to remove higher order reflections. The cell contacts are 25 spring loaded pins on the back, and one spring loaded pin on the top central busbar. The multi-pin back contact was found to be crucial for repeatable measurements. The current, typically about $7 \mu \mathrm{A}$ at $1600 \mathrm{~nm}$ for InGaAs cells, is amplified by a current-to-voltage amplifier $\left(10^{4} \mathrm{~A} / \mathrm{V}\right)$, and the resulting signal is measured by a Lock-in amplifier. The light intensity is measured by a calibrated (NIST traceable) pyroelectric detector. The system is completely computer controlled, with both data acquisition and analysis performed with LabVIEW software.

The repeatability of the measurements improved by making electrical contact resistances as low as possible. All electrical connections from the cell to the Lock-in amplifier are either gold-to-gold or soldered.

A probe resistor is required to account for the finite shunt resistances of the cells. The probe resistor is particularly critical for some of the recently developed InGaAsSb cells with shunt resistances as low as 1-2 ohms. For the probe resistor switched out of the circuit (Figure 1), the total cell current, $I_{v}$ is

$$
I_{t}=I\left(1+\frac{R_{M}}{R_{s}}\right) 。
$$

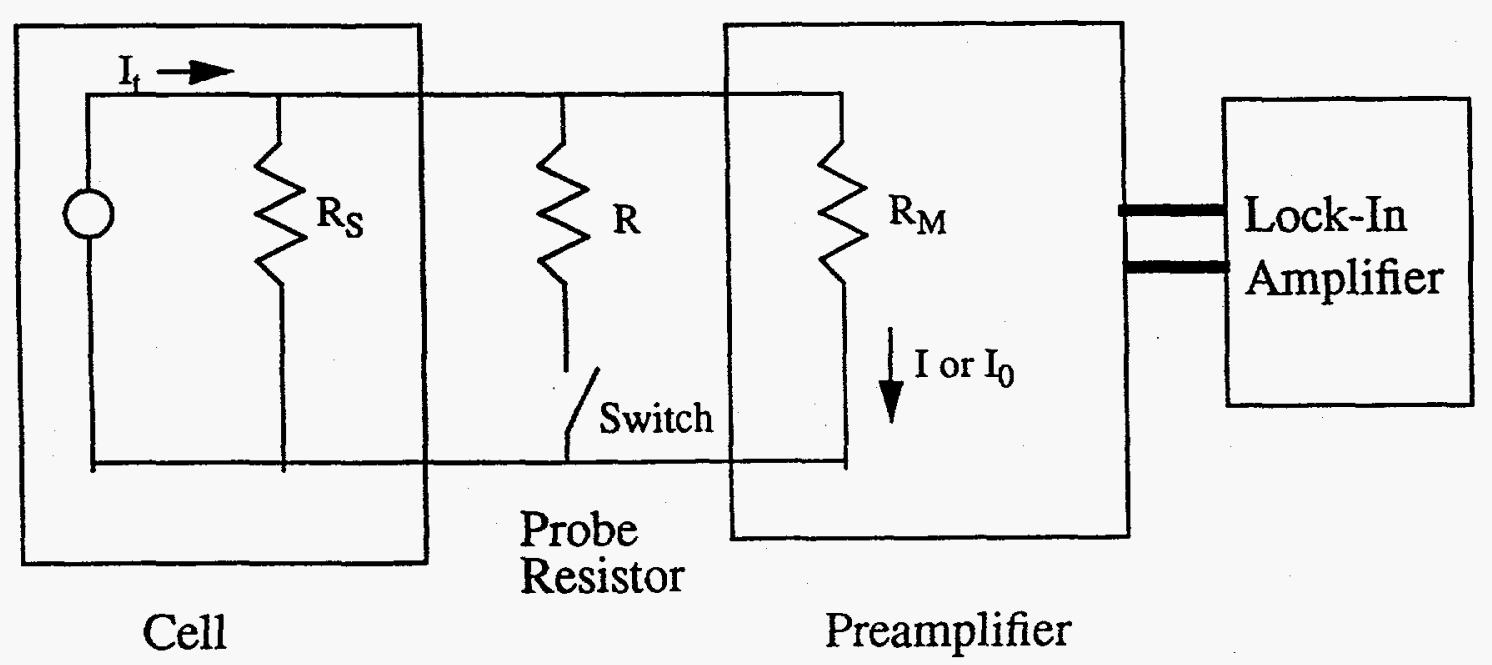

Figure 1. Electrical diagram of $\mathrm{QE}$ system showing the location of the probe resistor. 
where $I$ is the current through the preamplifier with the switch open, $R_{M}$ is the input impedance of the preamplifier, and $R_{S}$ is the shunt resistance of the TPV cell.

For the probe resistor switched in the circuit (Figure 1), the total cell current, $I_{v}$ is

$$
I_{t}=I_{0}\left(1+\frac{R_{u}}{R_{S}}+\frac{R_{u}}{R}\right) \text {, }
$$

where $\mathrm{I}_{0}$ is the current through the preamplifier with the switch closed, and $R$ is the resistance of the probe resistor. The basic working equation is obtained by combining Eq. 1 and Eq. 2 to eliminate $R_{s}$ :

$$
I_{t}=\frac{R_{M} I I_{0}}{R\left(I-I_{0}\right)} .
$$

The procedure is to first place a cell with a known high shunt resistance, $R_{S 1}$, on the fixture and calculate $R_{M} / R$ at one wavelength (e.g., $1600 \mathrm{~mm}$ ) according to

$$
\frac{R_{M}}{R}=\frac{1}{\frac{I_{0}}{I-I_{0}}-\frac{R}{R_{S_{1}}}} .
$$

The value of $R$ is chosen to be approximately equal to the value of the input impedance of the preamplifier in order for $I-I_{0}$ to be less than half of $I$. Note that the calculation of $R_{M} / R$ depends only weakly on $R$ and $R_{S 1}$, if $R$ is much smaller than $R_{S 1}$. This is easily arranged by selecting $R$ to be $1 \mathrm{ohm}$ and $R_{S 1}$ to be several hundred ohms.

The second part of the procedure is to place the sample cell on the fixture and calculate $I_{d} /\left(I-I_{0}\right)$ at a fixed wavelength, in this case $1600 \mathrm{~nm}$. The value of $I_{d}\left(I-I_{0}\right)$ was determined to be independent of wavelength. The final step is to run the $\mathrm{QE}$ measurement with the probe resistor out of the circuit and calculate $I_{t}$ according to Eq. 3.

The external QE's for cells with shunt resistances of $60.5 \mathrm{ohms}$ and $1.42 \mathrm{ohms}$ with and without the use of a probe resistor are shown in Figure 2. The proper accounting for the shunt resistance increases the $\mathrm{QE}$ at $1600 \mathrm{~nm}$ by $4.5 \%$ for the $60.5 \mathrm{ohm}$ cell and by $20.8 \%$ for the $1.42 \mathrm{ohm}$ cell.

As a check on the QE measurement system, the photon weighted integral of the external $\mathrm{QE}$ is compared to the measured short circuit current from a blackbody source at $1200 \mathrm{C}$ (see Figure 3). The measured and calculated currents are proportional, but not equal. This is because of view factor uncertainty and light absorption in the light pipe attached to the blackbody source. Any points which markedly deviate from the 


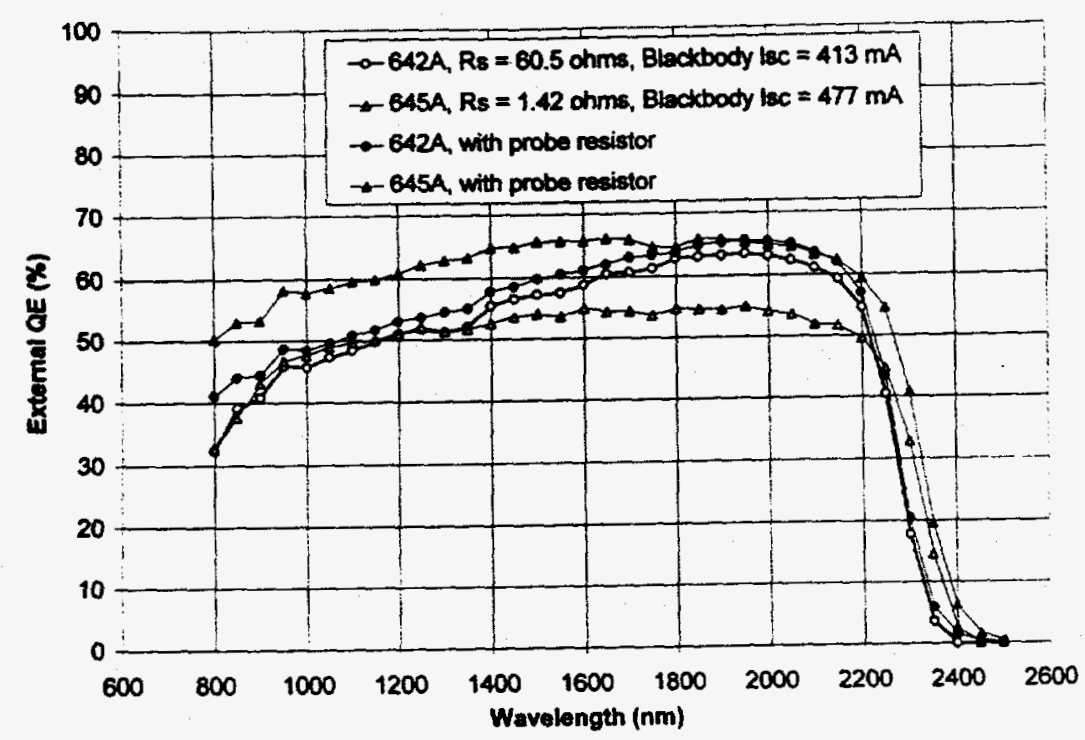

Figure 2. QE vs. wavelength showing the necessity of the probe resistor, especially for cells with low shunt resistances.

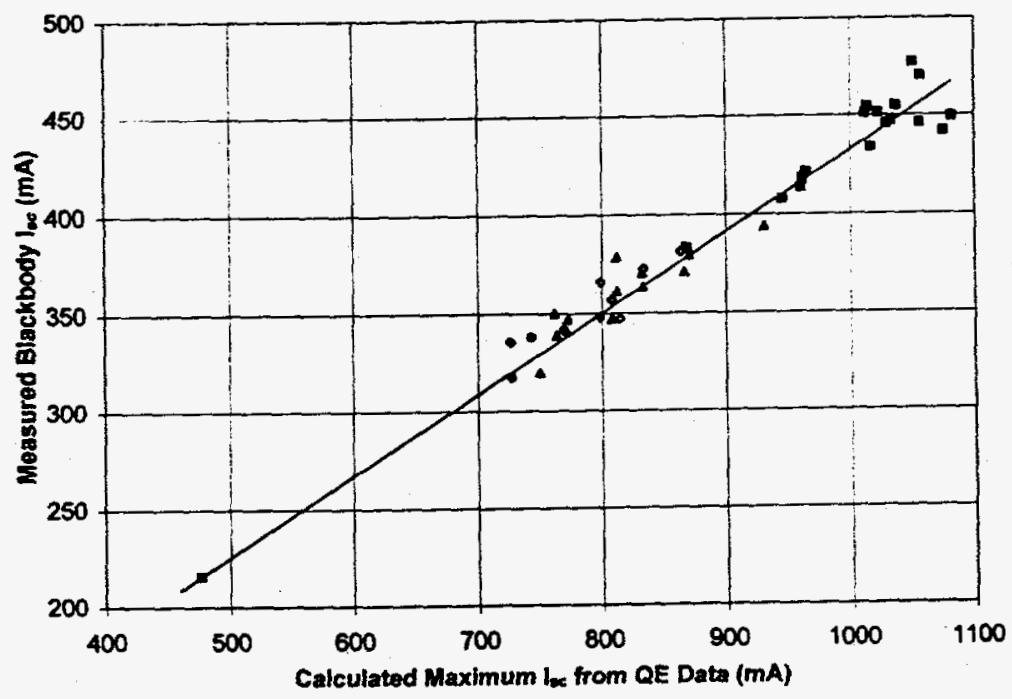

Figure 3. Plot showing a linear relationship between integrated $Q E$ vs. wavelength data and $I_{x c}$ measurements. Different symbols indicate different batches of cells.

straight line in Figure 3 act as a flag that there may be a measurement problem.

Wavelength dependent and average internal quantum efficiencies are calculated from the reflection data obtained with an Fourier Transform Infrared (FTIR) spectrometer (2). The internal $\mathrm{QE}$ is modeled with a program which inputs fundamental parameters 
including Auger and radiative recombination coefficients, Schockly-Reed-Hall hole and electron lifetimes, front and back surface recombination velocities, and absorption of cap layers.

\section{CURRENT-VOLTAGE MEASUREMENTS WITH A ROBOT}

A robot was designed and constructed to measure in less than a minute the cell dimensions and I-V curves under dark, blackbody, and flashlamp conditions (Figure 4). The computer-controlled system consists of a three axis linear track robot with a vacuum cell pickup, a cell width and length measurement stage, a moveable cell stage which translates linearly along a fourth axis linear track, a blackbody source, a flashlamp with a fast shutter, a curve tracer, a control box, and a computer. The data are displayed on the computer monitor and are saved as ASCII-type data files.

The sequence of a cell measurement is as follows. The vacuum pickup lifts a cell from a box of 25 and transports it to the X-Y measurement station. Two air-actuated probes position the sample against supports and measure the length and width of the cell.

The cell is next transported to the moveable stage. The electrical contacts to the cell consist of 25 spring loaded pins ( 24 for current, 1 for voltage) on the bottom of the cell, and 7 spring loaded pins ( 6 for current, 1 for voltage) on the top central busbar. As with the QE measurement system, these multi-pin probes are crucial to minimize errors due to back and front contact errors and to enhance repeatability. The spring constants of the pins are selected so that the 80 psi of air pressure applied to the top pins is sufficient to push the cell against a baseplate, which is maintained at $25 \mathrm{C}$.

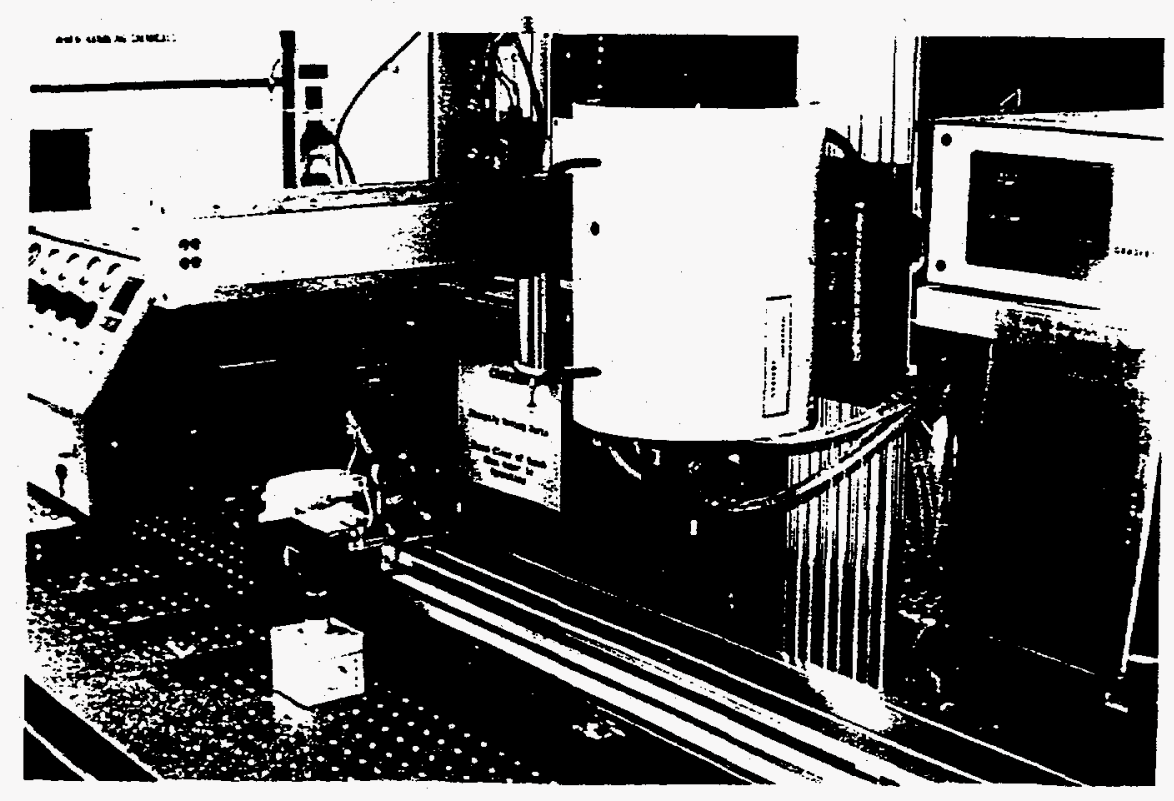

Figure 4. Photograph of automated robot for measurement of dark, blackbody, and illuminated I-V curves and cell dimensions. 
All I-V data are obtained with a Tektronix 370A curve tracer set to 2 sweeps with 512 data points per sweep. After a dark I-V measurement is performed, the cell is moved along the track and blackbody cell data is acquired. The blackbody source is held at $1200 \mathrm{C}$, and the light is concentrated with a gold-coated air-cooled light pipe inserted into the bottom of the blackbody source. The short circuit current $\left(\mathrm{I}_{x c}\right)$, open circuit voltage $\left(\mathrm{V}_{o c}\right)$, fill factor(FF), and maximum power $\left(\mathrm{P}_{\max }\right)$ are calculated, along with the mean and standard deviation of these parameters for a group of cells.

The cell is moved further along the track to the flashlamp illumination position. The high intensity flashlamp is energized, the high speed ( $5 \mathrm{~ms}$ to open and stabilize) shutter is opened, and the curve tracer collects the data. The configuration of the curve tracer requires that the data acquisition times are $\geq 200 \mathrm{msec}$. The values of $\mathrm{I}_{\infty} \mathrm{V}_{\infty} \mathrm{FF}$, and $\mathbf{P}_{\max }$ and statistical parameters are calculated as for the blackbody data. The cell is then transferred back to the box, another cell is picked up, and the process is repeated.

The maximum temperature rise of the cell during the flash test was estimated by measuring $V_{o c}$ as a function of time for lattice mismatched InGaAs and lattice matched InGaAsSb (both about $0.55 \mathrm{eV}$ ) cells. The decrease in $\mathrm{V}_{\alpha}$ after opening the shutter is approximately linear with time with a slope of $69 \mathrm{mV} / \mathrm{s}$ for InGaAsSb and $70 \mathrm{mV} / \mathrm{s}$ for InGaAsSb. The dependence of $\mathrm{V}_{x}$ on temperature is approximately $1.5 \mathrm{mV} / \mathrm{C}$ for lattice mismatched InGaAs and $1.45 \mathrm{mV} / \mathrm{C}$ for lattice matched InGaAsSb (3). The total time for the flash measurement is $200 \mathrm{msec}$, so the maximum temperature rise during the measurement is estimated to be $9 \mathrm{C}$. A comparison of $\mathrm{V}_{\propto}$ obtained by the robot flash test and by a steady state test with the cell soldered down show a difference of $4 \mathrm{mV}$. This indicates a temperature rise during the flash test of approximately $3 \mathrm{C}$.

An internally generated standard cell is run before and after each group of cells to verify the day to day measurement repeatability. The mean, standard deviation, and fractional percent deviation of the dimensional and electrical parameters for this standard cell are shown Table 1 . For all of the measurements, one standard deviation is less than $3 \%$.

A separate non-linear least squares fitting routine takes the dark I-V input data and performs a fit to the following equation for the I-V characteristics:

$$
I=-I_{L}+I_{S}\left[e^{\frac{g\left(V-I R_{s}\right)}{n k T}}-1-e^{\frac{-q\left(V-I R_{s}+V_{b}\right)}{b K T}}\right]+\frac{V-I R_{S}}{R_{S B}}
$$

where $I_{L}=$ light generated current, $I_{S}=$ saturation (dark) current, $V=$ voltage across the cell, $\mathrm{I}=$ current through the cell, $\mathbf{R}_{\mathrm{s}}=$ cell series resistance, $\mathrm{n}=$ ideality factor, $\mathrm{V}_{\mathrm{b}}=$ breakdown voltage, $\mathrm{b}=$ breakdown parameter, and $\mathrm{R}_{\mathrm{SH}}=$ cell shunt resistance. This equation modifies the ideal diode equation by accounting for Zener breakdown and for cell shunt resistance. The terms $I_{L}, I_{S}, R_{S}, n, V_{b}, b$, and $R_{S H}$ are possible adjustable parameters. The program performs the fit by minimizing the sum squared of the errors, by the Gauss-Newton method and singular value decomposition (SVD) for the 
Table 1. Measurement uncertainty for standard sample $\$ 2$ measured 30 times over 107 days.

\begin{tabular}{|l|l|l|l|l|}
\hline Measurement & I-V Type & Mean(M) & $\begin{array}{l}\text { Standard } \\
\text { Deviation ( })\end{array}$ & $\begin{array}{l}\text { Fractional Percent } \\
\left(100^{*} \sigma / M\right)\end{array}$ \\
\hline$V_{\text {oc }}(\mathrm{mV})$ & Blackbody & 235.7 & 2.1 & 0.9 \\
\hline $\mathrm{I}_{\boldsymbol{x}}(\mathrm{mA})$ & Blackbody & 340.4 & 2.4 & 0.7 \\
\hline $\mathrm{FF}(\%)$ & Blackbody & 64.9 & 1.0 & 1.6 \\
\hline $\mathrm{P}_{\max }(\mathrm{mW})$ & Blackbody & 52.1 & 1.3 & 2.5 \\
\hline $\mathrm{V}_{\text {oc }}(\mathrm{mV})$ & Flash & 305.2 & 2.0 & 0.7 \\
\hline $\mathrm{I}_{\boldsymbol{x}}(\mathrm{mA})$ & Flash & 2859.1 & 55.3 & 1.9 \\
\hline $\mathrm{FF}(\%)$ & Flash & 64.7 & 0.6 & 0.9 \\
\hline $\mathrm{P}_{\max }(\mathrm{mW})$ & Flash & 564.5 & 16.5 & 2.9 \\
\hline $\mathrm{X}(\mathrm{mm})$ & - & 10.40 & 0.03 & 0.3 \\
\hline $\mathrm{Y}(\mathrm{mm})$ & - & 10.32 & 0.03 & 0.3 \\
\hline
\end{tabular}

resulting system of equations (4). The parameters resulting from the data fit are input to a commercial electrical network modeling program (SABRE) to determine both the I-V characteristics and the electrical output power of a multicell TPV generator.

\section{OVERALL EFFICIENCY MEASUREMENTS}

The overall cell efficiency is measured by a calorimetric technique. Light from a calibrated blackbody source illuminates a cell soldered to a copper block. The block is fitted with a thermocouple, and is surrounded by gold shields on the top and by thermal insulation on the sides and bottom. The system is instrumented with current and voltage probes to measure the electrical characteristics of the cell. The rise in temperature after a shutter is pulled from the exit port is monitored by an automated data acquisition system.

If no heat losses occur, then the slope of the temperature vs. time curve is constant and can be used to calculate the heat absorbed by the cell. However, in real systems, there are losses due to conduction, convection, and radiation which cause a decrease in the slope of the temperature-time curve. The conduction and convection losses are proportional to the temperature difference $(\Delta \mathrm{T})$ between the cell and the ambient. For the small temperature differences we measured $(\Delta \mathrm{T} \leq 20 \mathrm{C})$, the radiant temperature loss is also well approximated by a linear dependence on $\Delta \mathrm{T}$. With these assumptions, the rate of temperature rise of the copper block for relatively small excursions above ambient can be written as 


$$
\mathrm{dT} / \mathrm{dt}=\mathrm{P}_{\mathrm{abo}} /\left(\mathrm{mC}_{\mathrm{p}}\right)-\mathrm{B} \Delta \mathrm{T},
$$

where $T$ is the cell temperature, $t$ is the time since the shutter was removed, $P_{\text {abs }}$ is the heat absorbed by the cell plus the block, $m$ is the mass of the cell plus block, $C_{p}$ is the specific heat of the cell plus block, $B$ is a heat loss parameter, and $\Delta T$ is the temperature rise of the cell above ambient.

A plot of $\mathrm{dT} / \mathrm{dt}$ vs. $\Delta \mathrm{T}$ should give a straight line with the $y$-intercept equal to

$$
(d T / d t)_{0}=P_{2 b 6} /\left(m_{p}\right) .
$$

A typical temperature vs. time curve is shown in Figure 5. A plot of dT/dt vs. $\Delta T$ (Figure 6) shows the expected linear behavior.

The system is calibrated by measuring the current (I) and the voltage (V) with the cell in reverse bias, so

$$
\mathrm{dT} / \mathrm{dt}=\mathrm{IV} /\left(\mathrm{mC}_{\mathrm{p}}\right)-\mathrm{B} \Delta \mathrm{T}
$$

and the y-intercept of the calibration run is

$$
(\mathrm{dT} / \mathrm{dt})_{0, \text { eql }}=\mathrm{IV} /\left(\mathrm{mC}_{\mathrm{p}}\right) .
$$

Dividing Eq. 7 by Eq. 9 yields

$$
P_{\mathrm{abs}}=\operatorname{IV}\left[(d T / d t)_{d}(d T / d t)_{0, c a t}\right]
$$

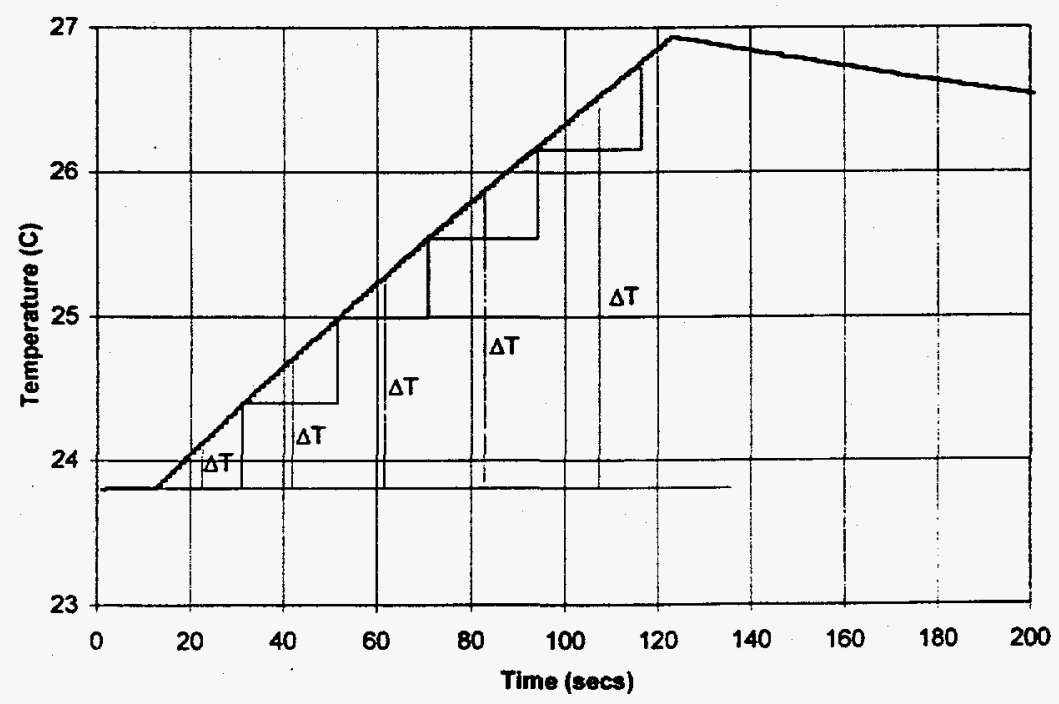

Figure 5. Temperature vs. time for overall efficiency test showing the multiple slope technique. 


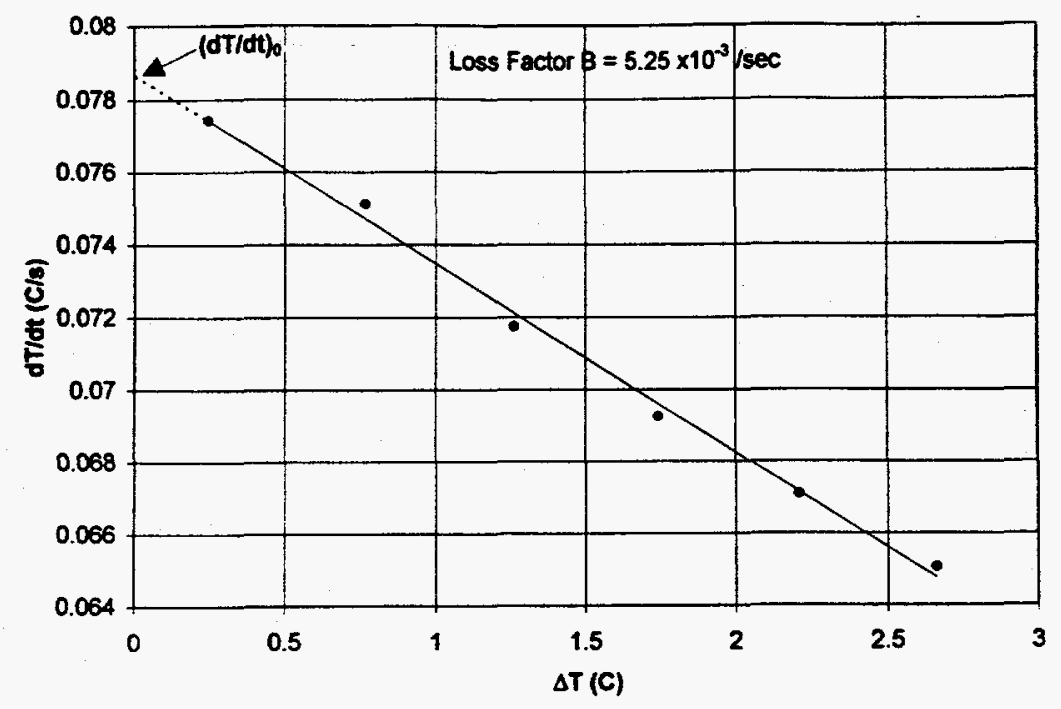

Figure 6. Rate of temperature rise of the copper block showing the "no heat loss" point at the $y$-intercept.

There are several advantages to this multiple slope method for measurement of overall efficiency as outlined above. The absorbed power is independent of specific heat and mass, since the system is calibrated by supplying a known power into the cell. This method accounts for losses due to conduction, convection, and radiation. Losses are extracted from a single normal run, so that no additional background runs are necessary. Approximately 100 data points are used to calculate the y-intercept. Finally, the method provides a quantitative value of the thermal losses in the system by providing the loss factor $\mathrm{B}$. This loss factor can help characterize the heat losses for various configurations of the copper block set-up.

The efficiencies measured directly in the copper block experiment are for relatively small currents, e.g., 0.5A. To calculate the efficiency expected at larger currents of $3 \mathrm{~A}$, for example, use the efficiency equations:

$$
\begin{aligned}
& \eta_{1}=\left(\mathrm{qV}_{\alpha} / \mathrm{E}_{\mathrm{Q}}\right)_{1}(\mathrm{FF})_{1}(\mathrm{QE})_{1}\left(\mathrm{~F}_{\mathrm{v}}\right)_{1}\left(\mathrm{~F}_{\mathrm{o}}\right)_{1} \\
& \eta_{2}=\left(\mathrm{qV}_{\alpha} / \mathrm{E}_{\mathrm{Q}}\right)_{2}(\mathrm{FF})_{2}(\mathrm{QE})_{2}\left(\mathrm{~F}_{v}\right)_{2}\left(\mathrm{~F}_{\mathrm{o}}\right)_{2},
\end{aligned}
$$

where $\eta$ is the efficiency, $q$ is the electronic charge, $V_{o c}$ is the open circuit voltage, $E_{G}$ is the band gap, FF is the fill factor, $\mathrm{QE}$ is the average internal quantum efficiency, $F_{u}$ is the spectral control factor, and $F_{0}$ is the "overexcitation" factor. The subscript " 1 " refers to the low current case directly measured by the copper block test, and the subscript "2" refers to the high current $(3 \mathrm{~A})$ case.

Since $F_{u}, F_{0}$, and $E_{0}$ do not depend on current, and we assume that the average $Q E$ 
does not change from $0.5 \mathrm{~A}$ to $3 \mathrm{~A}$, dividing Eq. 12 by Eq. 11 yields

$$
\eta_{2}=\eta_{1}\left[\left(\mathrm{~V}_{o c}\right)_{2}^{*}(\mathrm{FF})_{2} /\left(\mathrm{V}_{o c}\right)_{1}^{*}(\mathrm{FF})_{1}\right]
$$

The values of $\left(\mathrm{V}_{\mathrm{oc}}\right)_{2}$ and $(\mathrm{FF})_{2}$ are obtained from a steady state measurement with a cell soldered down or from a flash test.

\section{CONCLUSIONS}

The systems described above are used routinely to characterize TPV cells. The inclusion of a probe resistor in the quantum efficiency system is important to account for the low shunt resistances of some of the InGaAsSb cells. The multi-pin probes for both the quantum efficiency and the I-V measurements allow more repeatable and accurate measurements to be made.

The automated data acquisition of I-V curves by a robot has greatly facilitated the rapid quantitative evaluation of cells. The advantage of collecting two illuminated I-V curves is that the blackbody source provides a prototypical current for the cell at low illumination levels (about $0.4 \mathrm{~A}$ ), while the flashlamp provides prototypical open circuit voltages and fill factors at higher current levels (about $3 \mathrm{~A}$ ).

The calorimetric evaluation of overall cell efficiency is an accurate and convenient method. The calibration of the heat absorbed by applying a known power to the cell eliminates the need to know the specific heats of the copper block and the cell. The determination of the parasitic heat loss is a useful addition to the system.

Since no NIST standard TPV cell exists, round-robin measurements of standard laboratory cells among a variety of laboratories are recommended to identify and understand more fully the measurement uncertainty for these systems.

\section{REFERENCES}

1. J.P. Benner, T.J. Coutts, D.S. Ginley, eds.,The Second NREL Conference on the Thermophotovoltaic Generation of Electricity, AIP Conference Proceedings \#358, AIP Press, Woodbury, NY, 1995, p351.

2. J.L. Egley, D.M. Depoy, L.R. Danielson, M.J. Freeman, RJ. Dziendziel, J.F. Moynihan, P.F. Baldasaro, B.C. Campbell, C.A. Wang, H.K. Choi, G.W. Turner, S.J. Wojtczuk, P. Colter, P. Sharps, M. Timmons, R.E. Fahey, and K. Zhang, J. Elect. Mat., Vol 27, No. 9 (1998), 1138.

3. G.W. Charache, J.L. Egley, L.R. Danielson, D.M. Depoy, P.F. Baldasaro, and B.C. Campbell, Current Status of Low-Temperature Radiator Thermophotvoltaic Devices, presented at the 25th Photovoltaic Specialists Conference, Washington, D.C. 1996.

4. Numerical Recipes in C Press, Teukolsky, Vetterling and Flannery, Cambridge University Press, 1994. 